\title{
EVALUASI PENGGUNAAN RUANGAN BANGUNAN UNTUK MENGOPTIMALKAN UTILISASINYA PADA PEMAKAIAN GEDUNG FAKULTAS TEKNIK UNIVERSITAS PAKUAN.
}

\author{
Rorim Panday \\ Manajemen, Fakultas Ekonomi, Universitas Bhayangkara Jaya \\ Indripan@gmail.com
}

\begin{abstract}
ABSTRAK
Suatu bangunan mempunyai nilai ekonomi, terlebih lagi bangunan yang digunakan untuk kegiatan ekonomi seperti hotel, gedung perkantoran, bangunan gedung biasa atau rumah yang disewakan, bagunan gedung bertingkat yang disewakan, dalam satuan luas lantai ataukah dalam satuan unit lain, yang bisa digunakan untuk kegiatan bisnis atau non bisnis. Bangunan dalam satuan pendidikan, juga mempunyai nilai ekonomi, karena bangunan tersebut dibangun dan digunakan untuk mendidik baik siswa maupun mahasiswa. Dalam satuan pendidikan perguruan tinggi, diamati, jumlah mahasiswanya masih sedikit, sedangkan ruangan kelas masih banyak yang kosong/ idle tempat duduknya, sehingga kapasitasnya masih ada yang idle. Penelitian ini bertujuan untuk mengetahui seberapa besar nilai ekonomi suatu bangunan yang digunakan sebagai ruangan kelas, dari segi nilai ekonominya yang disebut dengan space utility. Penelitian ini adalah studi kasus pada gedung Fakultas Teknik universitas Pakuan, Bogor. Data yang digunakan adalah data sekunder yang berkaitan dengan jumlah mahasiswa yang mengambil matakuliah dan data penggunaan ruangan untuk perkuliahan. Dari data tersebut diketahui nilai okupansi dan nilai frekuensi pemakaian ruangan. Hasil penelitian ini menunjukkan bahwa Space utility dari penggunaan gedung fakultas teknik universitas Pakuan rata-rata adalah sebesar 14,19\%. Berdasarkan hasil tersebut perlu adanya strategi untuk meningkatkan ulitisasi penggunaan ruangan dengan cara meningkatkan okupansi ruangan dan frekuensi pemakaian ruangan.
\end{abstract}

Kata kunci: Nilai ekonomi, okupansi, frekuensi pemakaian, space utility

\begin{abstract}
A building has economic value, moreover, buildings used for economic activities such as hotels, office buildings, buildings or houses for rent, high rise buildings leased, in the unit area or other units, which can be used for business activities or non-business. The educational building unit, also has economic value, since the building was built and used to educate both students and college students. In units of college education, observed, the number of students is still a less, while the classrooms are still many empty / idle seat, so there is still idle capacity. This study aims to determine how much the economic value of a building used as a classroom, in terms of economic value called space utility. This research is a case study on the building of the Faculty of Engineering of Pakuan University, Bogor. The data used are secondary data relating to the number of students who take the course and usage
\end{abstract}


data for the class room. From those data, known the occupancy rate and the frequency value of usage room. The results of this study indicate that the space utility of the use of the engineering faculty building of Pakuan university in average as $14.19 \%$. Based on these results, need a strategy to improve the space utility by increasing occupancy room and usage frequency room.

Keywords: Econnomis value, occupancy, frequency of usage, space utility

\section{PENDAHULUAN}

Ada banyak cara untuk menilai kegunaan suatu bangunan dilihat dari berbagai aspek, seperti aspek efisiensi penggunaan energi pada gedung yang berkaitan dengan penggunaan energi listrik, energi pendingin ruangan/ temperature. Sisi lain dilihat dari segi financial yang dapat dihasilkan dari komersialisasi suatu bangunan. Dan dapat juga dilihat dari segi cost dan benefitnya, dari segi efektifitas dan efisiensinya. Ada juga dari segi usage level. Untuk itu dalam perencanaan pembuatan gedung seharusnya disertai dengan perencanaan bagaimana mengoptimalisaikan penggunaannya, sehingga memberikan nilai ekonomi yang tinggi.

Suatu bangunan mempunyai nilai ekonomi, terlebih lagi bangunan yang digunakan untuk kegiatan ekonomi seperti bangunan gedung biasa atau rumah yang disewakan atau dikontrakkan, bagunan gedung bertingkat yang disewakan atau dikontrakkan, apakah dalam satuan luas lantai ataukah dalam satuan unit yang bisa digunakan untuk kegiatan bisnis atau non bisnis seperti untuk tempat tinggal. Bangunan dalam satuan pendidikan, juga mempunyai nilai ekonomi, karena bangunan tersebut dibangun dan digunakan untuk mendidik baik siswa maupun mahasiswa.

Dalam pelaksanaan akademik di fakultas teknik Universitas Pakuan, dipergunakan sarana akademik baik fasilitas yang ada di lingkungan gedung fakultas teknik maupun yang berada dalam pengelolaan Universitas Pakuan seperti terlihat pada tabel-1.

Tabel 1 Sarana Akademik Fakultas Teknik - UNPAK

\begin{tabular}{|l|c|c|c|c|}
\hline \multicolumn{1}{|c|}{ Jenis } & Unit & $\begin{array}{c}\text { Luas } \\
\left(\mathbf{m}^{\mathbf{2}}\right)\end{array}$ & Lokasi & Keterangan \\
\hline Aula & 2 & 144 & FT Lt. III & \\
\hline Ruang Kuliah & 5 & 360 & FT. Lt. II & \\
\hline Ruang Kuliah & 6 & 432 & FT. Lt. III & \\
\hline
\end{tabular}




\begin{tabular}{|l|c|c|c|c|}
\hline Ruang GTC & 2 & 144 & FT. Lt. II & \\
\hline $\begin{array}{l}\text { Ruang Penyimpanan } \\
\text { OHP }\end{array}$ & 1 & 12 & FT. Lt. III & 9 buah \\
\hline Laboratorium & 3 & 324 & FT. Lt. II & $\begin{array}{c}\text { Dilengkapi Peralatan } \\
\text { Praktikum / Penelitian }\end{array}$ \\
\hline Studio & 2 & 72 & FT. Lt. III & $\begin{array}{c}\text { Dilengkapi Peralatan } \\
\text { Gambar / Praktikum }\end{array}$ \\
\hline $\begin{array}{l}\text { Laboratorium Mekanika } \\
\text { Tanah }\end{array}$ & 1 & 108 & FT. Lt. I & $\begin{array}{c}\text { Dilengkapi Peralatan } \\
\text { Praktikum / Penelitian }\end{array}$ \\
\hline Ruang Lab. Transportasi & 1 & 6 & FT. Lt. III & \\
\hline Workshop & 1 & 6 & FT. Lt. II & \\
\hline Ruang Sidang & 2 & 54 & FT. Lt. III & \\
\hline Lab Bahasa & 1 & 108 & UNPAK & \\
\hline Laboratorium Komputer & 1 & 32 & FT. Lt. I & Dilengkapi Komputer \\
\hline
\end{tabular}

Dari ruangan dan fasilitas yang ada tersebut, 16 ruangan ditetapkan oleh pengelola fakultas teknik sebagai ruang kuliah. Untuk ruangan kuliah ditetapkan oleh pihak universitas kapasitasnya 40 orang untuk satu kelas atau satu mata kuliah. Kenyataannya setiap kelas/ setiap mata kuliah jumlah mahasiswa yang mengambil mata kuliah tersebut kurang dari 40 orang. Kegiatan kuliah di tetapkan 8 jam per hari. Kenyataan juga ada ruang kuliah yang pemakaiannya kurang dari 8 jam per harinya. Perkuliah yang berlangsung di fakultas teknik adalah 6 hari, dari hari Senin sampai dengan hari Sabtu. Menarik dari kasus ini berapa okupansi dari ruangan kuliah di fakultas teknik UNPAK? Berapa persentase frekuensi penggunaaan ruang kuliah? Dan berapa nilai space utility dari pemakaian ruangan pada fakultas teknik UNPAK?

\section{LANDASAN TEORI, DAN KAJIAN EMPIRIS}

Pengukuran penggunaan ruangan beberapa peneliti/ penulis menggunakan teori utilisasi, kapasitas dan okupansi. Kapasitas perlu ditetapkan dalam perencanaan ruangan dari bangunan, karena mempengaruhi sebagian besar biaya tetap. Dengan kapasitas yang direncanakan juga menentukan apakah permintaan dapat dipenuhi, atau apakah fasilitas yang ada akan berlebihan. (Martinich, 1997).

Jika kapasitas terlalu besar, sebagian kapasitas kemungkinan akan menganggur (idle) dan akan terdapat biaya tambahan yang dibebankan pada proses produksi yang ada 
atau dibebankan kepada pelanggan. Sebaliknya jika kapasitas terlalu kecil, keinginan pelanggan tidak dapat dilayani dan bahkan sebagian peluang pasar akan hilang.

Oleh karena itu penetapan ukuran kapasitas, dengan tujuan pencapaian tingkat utilisasi tinggi dan tingkat pengembalian investasi yang tinggi, serta ukuran efisiensi sangat menentukan. Dengan perencanaan kapasitas yang akurat sebuah perguruan tinggi akan dapat mengetahui jumlah permintaan yang dapat dilayani dengan standar kualitas yang telah ditentukan. Perencanaan kapasitas harus dipandang dari tiga perspektif (Heizer 2008: 167), yaitu (1) kapasitas design, keluaran maksimum pada kondisi ideal, (2) kapasitas efektif, keluaran maksimum pada tingkat keluaran maksimum operasi tertentu dan (3) kapasitas aktual, keluaran nyata yang dapat dihasilkan oleh sebuah fasilitas. Kondisi yang baik adalah kapasitas aktual sama dengan kapasitas efektif.

Utilisasi ruangan adalah untuk mengukur apakah dan bagaimanakah ruangan digunakan.Tingkat utilisasi adalah fungsi dari tingkat frekuensi dan tingkat okupansi. Tingkat frekuensi adalah mengukur perbandingan antara waktu penggunaan ruangan dengan waktu penggunaan ruang yang tersedia, dan tingkat okupansi adalah mengukur seberapa penuh ruangan dibandingkan dengan kapasitasnya. Tingkat utilisasi dapat dinilai dalam bentuk aktual penggunaan dan prediksi penggunaan.

Pada UK Higher Education. (2006), utilisasi ruangan biasanya didefinisikan untuk mengukur bagaimana ruangan digunakan, baik dalam bentuk seberapa sering ruangan digunakan dan, kapan mereka menggunakan, berapa banyak orang didalamnya.

Dalam UK Higher Education. (2006), the National Audit Office's (NAO) Space Management inHigher Education (2006) : A Good Practice Guide (1996) menentukan perhitungan standar :

Space Utilisasion $=(\%$ frequency $\mathrm{x} \%$ occupancy $) / 100$

Dimana:

$\%$ frekuensi adalah proporsi banyaknya jam pemakaian ruangan terhadap total jam yang tersedia per minggu

$\%$ okupansi adalah proporsi ukuran rata-rata kelompok terhadap kapasitas total untuk jam pemakaian ruangan. 
Hesti (2010), melakukan penelitian terhadap optimalisasi kapasitas ruangan, dikaitkan dengan kapasitas minimum yang dicari dengan menggunakan prinsip Break even point dan linier programmimg. Pada penelitiannya menggunakan beberapa asumsi. Untuk Pengukuran Utilitas, Hesti memakai Utilisasi (utilization) sebagai persentase kapasitas desain yang sesungguhnya telah dicapai. Sedangkan Utilisasi = Output aktual: Kapasitas desain. Untuk pengukuran efisiensi (Heizer, 2008: 158), Efisiensi adalah persentase kapasitas efektif yang sesungguhnya telah dicapai. Manajer operasi cenderung dievaluasi pada tingkat efisiensinya. Sehingga, Efisiensi = output aktual: kapasitas efektif. Untuk menentukan output aktual maka: Output aktual $=$ kapasitas efektif $\times$ efisiensi. Rumus yang digunakan Hesti sedikit berbeda dengan UK Higher Education. Dalam penelitian ini, peneliti menggunakan rumus dari UK Higher Education.

\section{METODE}

Penelitian ini adalah penelitian dengan studi kasus. Untuk penelitian ini akan ditentukan space utility dari gedung fakultas teknik universitas Pakuan Bogor. Metode penelitian yang digunakan adalah metode kuantitatif dengan menggunakan data sekunder. Data yang diperlukan adalah data jumlah mahasiswa yang mengambil mata kuliah di fakultas teknik dan data jawal pemakaian ruangan kuliah. Untuk penelitian ini data yang diambil adalah data pada tahun ajaran 2012/2013 dari semester ganjil dan semester genap. Dari kedua data tersebut dapat dihitung okupansi pemakaian ruang kelas/ ruang kuliah dan persentase frekuensi penggunaan ruang kuliah. Dengan menggunakan program Excel, maka dapat dibuat hitungan dan simulasi bagaimana caranya untuk dapat meningkatkan space utility dari ruang kelas di gedung fakultas teknik.

\section{HASIL DAN PEMBAHASAN}

Data pemakaian ruangan kelas berupa data sekunder dari file excel yang ada di fakultas teknik. Contoh data penggunaan kelas seperti gambar-1. Pada pembuatan jadwal pemakaian ruang kelas digunakan beberapa ketentuan jam mata kuliah yaitu ada yang 1,5 jam, 2 jam dan 3 jam. Untuk data pemakaian satu ruangan dibuat 
jadwalnya seperti gambar-1. Di Fakultas teknik terdapat 16 ruangan yang ditetapkan sebagai ruang kuliah. Pada gambar-1, terlihat bahwa pemakaian ruang kelas belum optimum. Selanjutnya pemakaian ruangan kelas ditetapkan dalam satu hari adalah 8 jam, mulai dari jam 8 pagi sampai dengan jam 4 sore, jadi pemakaiannya adalah 4 kali dalam satu hari. Dari data yang dikumpulkan, pada kenyataannya ada juga ruangan yang penggunaannnya lebih dari 8 jam atau 4 kali pemakaian.

\begin{tabular}{|c|c|c|c|c|c|c|}
\hline & & $\begin{array}{l}\text { DWAL MATA } \\
\text { GEDUN } \\
\text { FAKULTA } \\
\text { PERIOD }\end{array}$ & $\begin{array}{l}\text { KULIAH UNTUK } \\
\text { FAKULTAS TEK } \\
\text { TEKNIK - UNIVE } \\
\text { SEMESTER GA }\end{array}$ & $\begin{array}{l}\text { AKAIAN RUAN } \\
\text { LANTAI III } \\
\text { TAS PAKUAN } \\
2012 / 2013\end{array}$ & & \\
\hline \multicolumn{7}{|c|}{ RUANGAN 310 (PWK) } \\
\hline MEKTU HAF & SENN & seass & RLBU & KaUs & JUNAT & SLSTU \\
\hline \begin{tabular}{|l|}
$08.00-09.00$ \\
$09.00-10.00$ \\
\end{tabular} & Kolkulus 1 & $\begin{array}{l}\text { Perenc. Pengemb. Wil. } \\
\text { Pesisir \& Kelsutan }\end{array}$ & $\begin{array}{l}\text { Hukum Administrasi } \\
\text { Perencansan }\end{array}$ & \multirow{2}{*}{$\begin{array}{c}\text { Elektroniks } \\
\text { Telekomunikssi } \\
\text { (Elektro) }\end{array}$} & & $\begin{array}{l}\text { Dasar Sistem Kontrol } \\
\text { (Elektro) }\end{array}$ \\
\hline $10.00-11.00$ & & \multirow{2}{*}{$\begin{array}{c}\text { Management Sumber } \\
\text { Days Air (Geologi]) }\end{array}$} & \multirow{2}{*}{$\begin{array}{l}\text { Pengantar Proses } \\
\text { Perencansan }\end{array}$} & & & \multirow{2}{*}{$\begin{array}{l}\text { Well Logging } \\
\text { [Geologi] }\end{array}$} \\
\hline $11.00-12.00$ & & & & $\begin{array}{l}\text { Ekonomi Teknik } \\
\text { (Elektro) }\end{array}$ & & \\
\hline $12.00-13.00$ & & & & & & Pemrog. Sist. \\
\hline $13.00-14.00$ & & \multirow{2}{*}{$\begin{array}{l}\text { Aljsbser } \\
\text { Linier }\end{array}$} & & & & Telekom (Elehtro) \\
\hline $14.00-15.00$ & & & & & & \multirow{2}{*}{$\begin{array}{l}\text { Dasar Mikroprosesor } \\
\text { (Elektro) }\end{array}$} \\
\hline $15.00-16.00$ & & & & & & \\
\hline \multicolumn{7}{|l|}{$16.00-17.00$} \\
\hline \multicolumn{7}{|l|}{$17.00-18.00$} \\
\hline \multicolumn{7}{|l|}{$18.00-19.00$} \\
\hline \multicolumn{7}{|l|}{$19.00-20.00$} \\
\hline $20.00-21.00$ & & & & & & \\
\hline
\end{tabular}

Gambar-1. Contoh data penggunaan kelas di fakultas teknik.

Contoh data jumlah mahasiswa yang mengambil mata kuliah seperti pada gambar-2. Data ini adalah jadwal ujian akhir semester. Kenapa menggunakan data ini, karena pada data ini, jumlah mahasiswa yang mengambil matakuliah sudah fix.

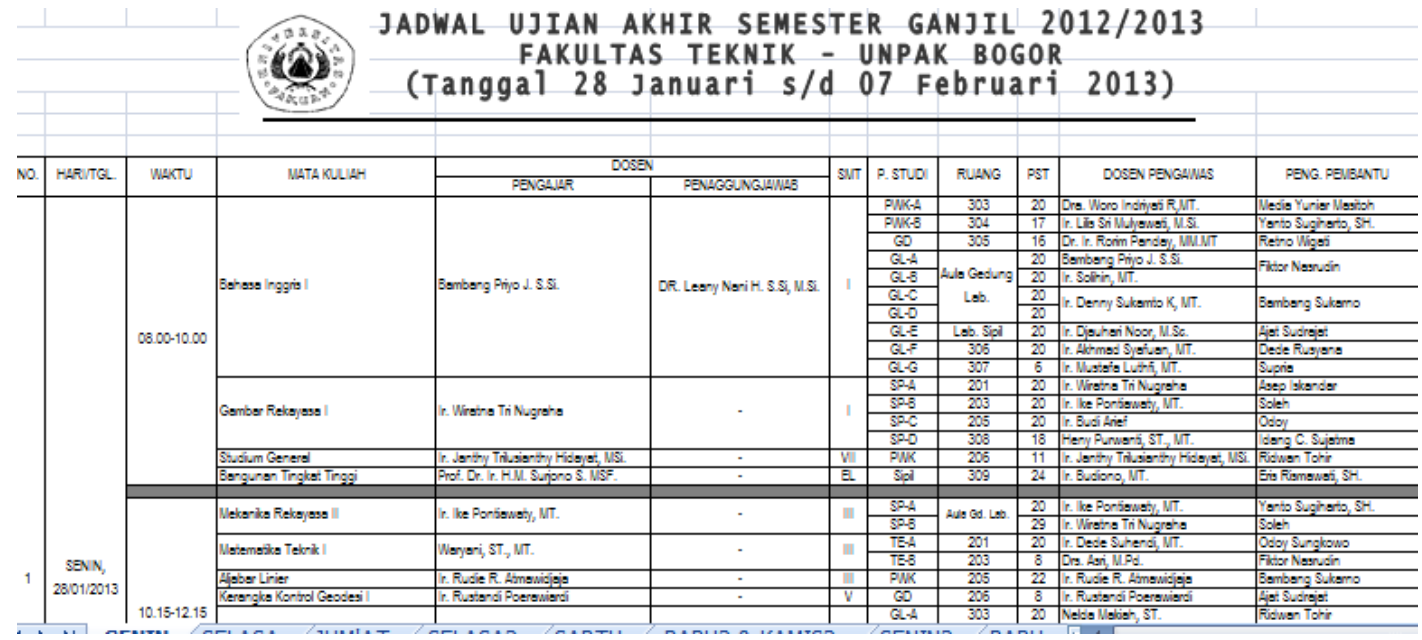

Gambar-2. Contoh data jumlah mahasiswa yang mengambil matakuliah di fakultas teknik. 
Berdasarkan data jumlah mahasiswa yang mengambil mata kuliah, mata dapat dihitung jumlah mahasiswa yang menggunakan ruang kuliah di semester ganjil dan semester genap. Hasil hitungan okupansi dapat dilihat pada tabel-2. Jumlah okupansi, dalam hal ini pemakaian ruang kuliah di semester ganjil adalah sebanyak 5275 orang, padahal kapasitas daya tampung 16 ruangan bila digunakan 6 hari dalam satu minggu, satu ruangannya 40 orang, dan satu hari dipakai sebanyak 4 kali, maka kapasitas maksimumnya adalah 15360 orang. Sehingga okupansi pemakaian ruang kelas di semester ganjil adalah sebesar 34,34 \%, sedangkan okupansi pemakaian ruangan kuliah di semster genap adalah sebesar 28,35\%. Terjadi perbedaan nilai okupansi, karena jumlah mahasiswa yang mengambil matakuliah disemester ganjil lebih banyak dari jumlah mahasiswa di semester genap. Di semester ganjil jumlah mahasiswanya lebih banyak, karena adanya tambahan mahasiswa baru, sedangan di semester genap jumlah mahasiswanya berkurang karena adanya mahasiswa yang diwisuda.

Tabel-2 Hitungan Occupancy pemakaian ruangan kelas semester ganjil dan genap

\begin{tabular}{|l|r|}
\hline Jumlah mahasiswa yg menggunakan ruangan \\
\hline Semester ganjil & \\
\hline & 737 \\
\hline Senin & 649 \\
\hline Selasa & 429 \\
\hline Jumat & 696 \\
\hline selasa2 & 526 \\
\hline sabtu & 368 \\
\hline rabu\%kamis & 440 \\
\hline Senin2 & 713 \\
\hline Rabu & 717 \\
\hline Kamis & 5275 \\
\hline Total= & 15360 \\
\hline Kapasitas tampung & 34,34 \\
\hline Occupancy= & \\
\hline
\end{tabular}

\begin{tabular}{|l|r|}
\hline Jumlah mahasiswa yg menggunakan ruangan \\
\hline Semester Genap & \\
\hline & \\
\hline Senin & 618 \\
\hline Selasa & 597 \\
\hline Selasa2 & 286 \\
\hline Senin2 & 580 \\
\hline Sabtu & 627 \\
\hline Jumat & 467 \\
\hline Kamis & 570 \\
\hline rabu & 609 \\
\hline & \\
\hline Total= & 4354 \\
\hline Kapasitas tampung= & 15360 \\
\hline Occupancy= & 28,35 \\
\hline
\end{tabular}

Untuk menghitung \% frekuensi pemakaian ruang kuliah, ditetapkan pemakaian ruang kuliah dalam satu hari adalah 4 kali atau dalam waktu 8 jam. Ruang kuliah digunakan dalam satu minggu selama 6 hari. Kapasitas satu ruang kuliah ditetapkan 40 mahasiswa. Berdasarkan data pemakaian ruang kuliah dan ketentuan tersebut dapat dihitungan persentase frekuensi pemakaian ruang kuliah seperti terlihat pada tabel-3. Pada tabel-3, untuk semester ganjil, Persentase terendah adalah ruang $311 \mathrm{Gl}$ 
sebesar 27,08\% dan persentase tertinggi adalah ruang kuliah 201 GL sebesar $73,96 \%$. Rata-rata persentase frekuensi adalah 51,04\%.

Tabel-3. Hitungan \% frekuensi pemakaian jam ruangan kelas- senester ganjil

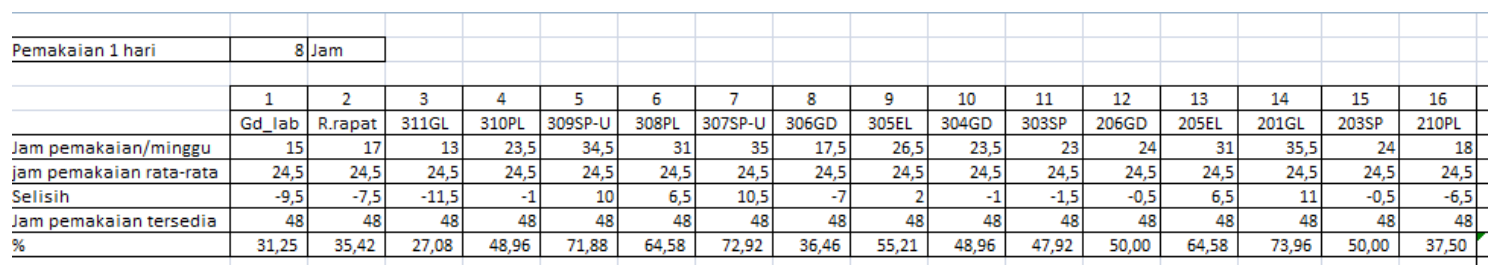

Pada tabel-4, untuk semester genap, persentase terendah adalah ruang 310 PL sebesar 5,21\% dan persentase tertinggi adalah ruang kuliah gedung Lab sebesar $72,92 \%$. Rata-rata persentase frekuensi adalah 38,28 \%. Dalam bentuk grafik, jam penggunaan ruang kuliah pada semester ganjil pada gambar-3, dan jam penggunaan ruang kuliah pada semester genap pada gambar-4.

Tabel-4. Hitungan \% frekuensi pemakaian jam ruangan kelas- senester genap

\begin{tabular}{|c|c|c|c|c|c|c|c|c|c|c|c|c|c|c|c|c|}
\hline & 1 & 2 & 3 & 4 & 5 & 6 & 7 & 8 & 9 & 10 & 11 & 12 & 13 & 14 & 15 & 16 \\
\hline & Gd_lab & \begin{tabular}{|l|} 
R.rapat \\
\end{tabular} & $311 \mathrm{GL}$ & $310 \mathrm{PL}$ & $309 S P-U$ & $308 \mathrm{PL}$ & $307 \mathrm{SP}-\mathrm{U}$ & $306 \mathrm{GD}$ & 305EL & $304 \mathrm{GD}$ & $303 \mathrm{SP}$ & $206 \mathrm{GD}$ & 205EL & $201 \mathrm{GL}$ & $203 \mathrm{SP}$ & $210 \mathrm{PL}$ \\
\hline Jam permakaian/miningu & 35 & 14 & 10 & 2,5 & 15,5 & 18 & \begin{tabular}{|l|}
24,5 \\
\end{tabular} & 20,5 & 19,5 & \begin{tabular}{|r|}
12 \\
\end{tabular} & 12 & 22,5 & 30,5 & 14,5 & 26,5 & 16,5 \\
\hline jam pemakaian rata-rata & 18,375 & 18,375 & 18,375 & 18,375 & 18,375 & 18,375 & 18,375 & 18,375 & 18,375 & 18,375 & 18,375 & 18,375 & 18,375 & 18,375 & 18,375 & 18,375 \\
\hline Selisih & 16,625 & $-4,375$ & $-8,375$ & $-15,875$ & $-2,875$ & $-0,375$ & 6.125 & 2,125 & 1,125 & $-6,375$ & $-6,375$ & 4,125 & 12,125 & $-3,875$ & 8.125 & $-1,875$ \\
\hline Jam pemakaian tersedia & 48 & 48 & 48 & 48 & 48 & 48 & 48 & 48 & 48 & 48 & 48 & 48 & 48 & 48 & 48 & 48 \\
\hline$\%$ & 72,92 & 29,17 & 20,83 & 5,21 & 32,29 & 37,50 & 51,04 & 42,71 & 40,63 & 25,00 & 25,00 & 46,88 & 63,54 & 30,21 & 55,21 & 34,38 \\
\hline
\end{tabular}

Untuk semester Ganjil (gambar-3), terlihat ada 6 ruangan yang jam pemakaiannya per minggu di atas jam pemakaian rata-rata per minggu, sedangkan 10 ruangan jam pemakaiannya per minggu masih di bawah jam pemakaian rata-rata per minggu. Namun demikian, jam pemakaian 16 ruangan, masing-masing ruangan masih jauh di bawah jam pemakaian per minggu yang tersedia, yaitu 48 jam.

Untuk semester Genap (gambar-4), terlihat ada 7 ruangan yang jam pemakaiaannya per minggu di atas jam pemakaian rata-rata per minggu, sedangkan 9 ruangan jam pemakaiannya per minggu masih di bawah jam pemakaian rata-rata per minggu. Namun demikian, jam pemakaian 16 ruangan, masing-masing ruangan masih jauh di bawah jam pemakaian per minggu yang tersedia, yaitu 48 jam. 


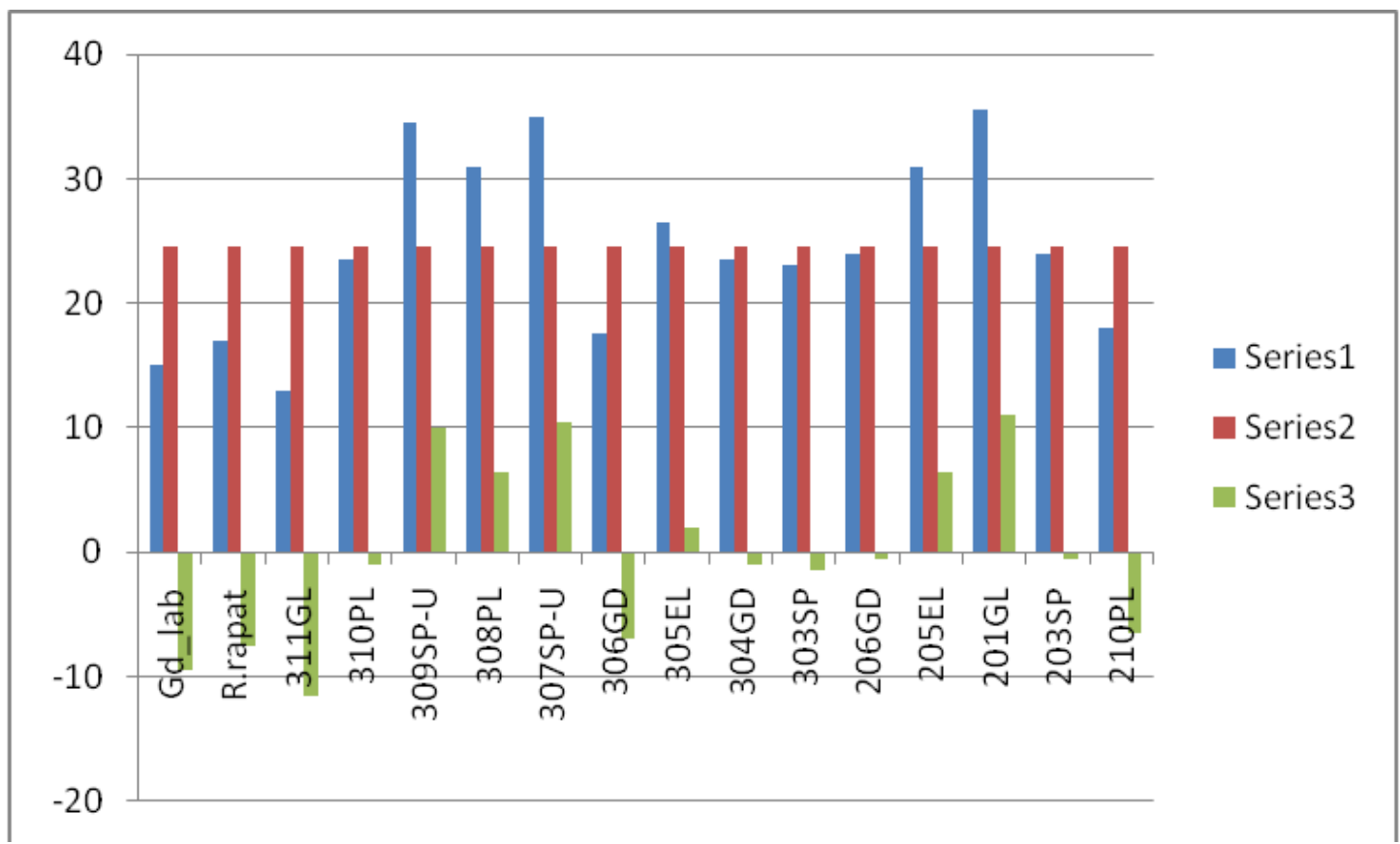

Gambar 3. Jam Penggunaan ruangan kelas semester ganjil 2012/2013

Catatan: Merah: jam pemakaian rata-rata / minggu

Biru : aktual jam pemakaian / minggu

Hijau: selisih antara aktual jam pemakaian- jam pemakaian rata-rata /minggu

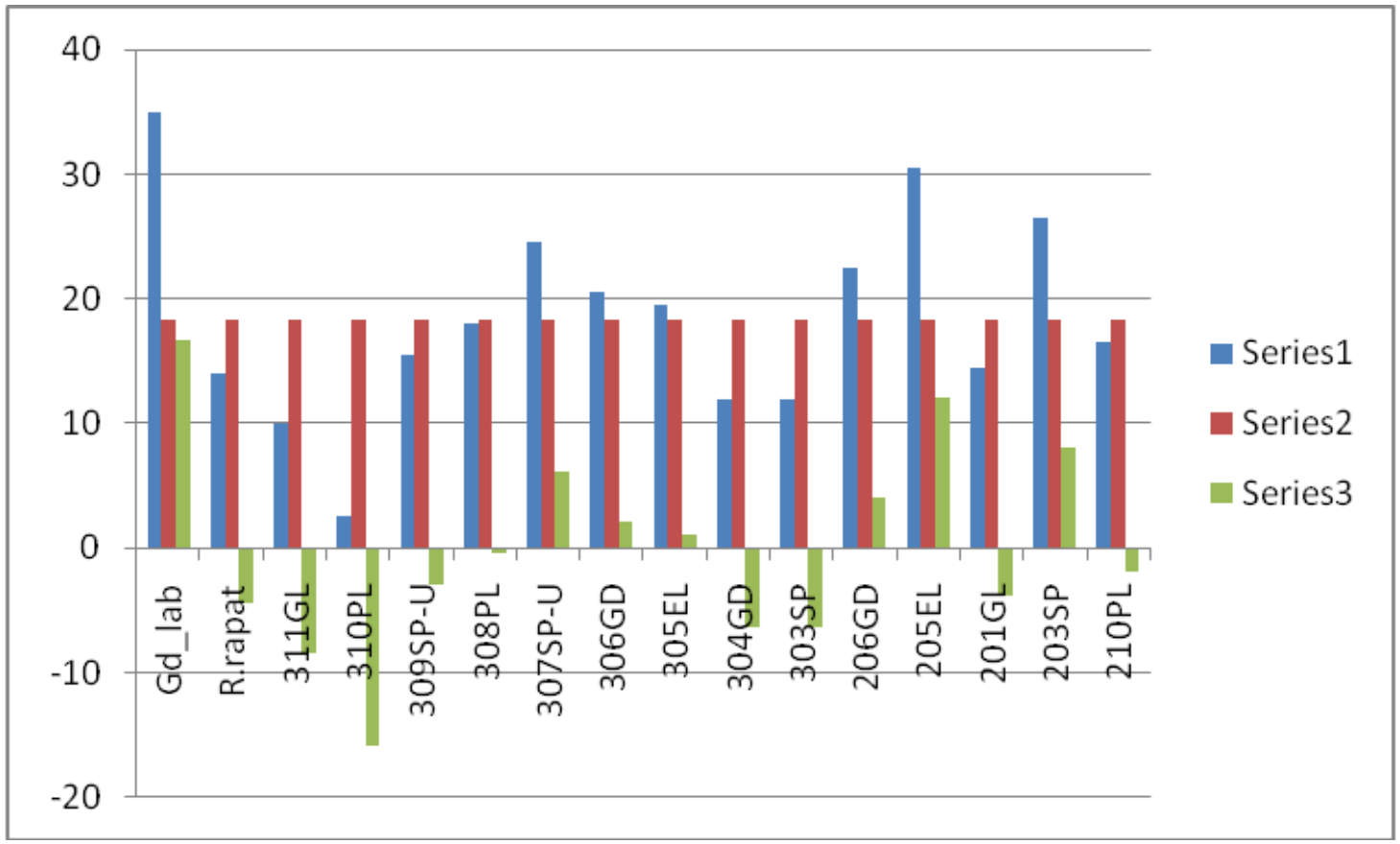

Gambar 4. Jam Penggunaan ruangan kelas semester genap 2012/2013 Catatan: Merah: jam pemakaian rata-rata / minggu

Biru : aktual jam pemakaian / minggu

Hijau: selisih antara aktual jam pemakaian- jam pemakaian rata-rata /minggu 
Berdasarkan nilai rata-rata okupansi dan nilai rata-rata presentase frekuensi, maka dapat dihitung Space utility untuk setiap semester. Space utility untuk semester ganjil adalah 17,53 persen dan space utility untuk semester genap adalah 10,85\%. Space utility rata-rata adalah 14,19\%. Dengan demikian idle dari space utility adalah $85,81 \%$. Dengan demikian nilai ekonomi yang dimanfaatkan oleh gedung fakultas teknik masih kecil. Ada opportunity ekonomi yang belum dimanfaatkan sebesar $85,81 \%$. Space utility dari ruangan kelas tersebut dapat ditingkatkan dengan meningkatkan jumlah mahasiswa untuk meningkatkan okupansi, memperkecil kapasitas ruangan sesuai ketentuan, dalam hal ini ketentuan dari kementerian pendidikan dan kebudayaan dalam Standar Nasional Pendidikan (2005), yaitu 30 mahasiswa kapasitas maksimumnya untuk prodi non-eksakta dan 20 mahasiswa untuk prodi eksakta. Hal ini dapat di perlihat dari hasil simulasi dibawah ini.

Tabel-4 Hasil hitungan Space utility

\begin{tabular}{|c|c|c|c|c|c|}
\hline & $\begin{array}{c}\text { No of } \\
\text { Classroom }\end{array}$ & $\begin{array}{c}\text { Maximum } \\
\text { Capacity }\end{array}$ & $\begin{array}{c}\text { usage } \\
\text { (hours) }\end{array}$ & $\begin{array}{l}\text { Space } \\
\text { utility }\end{array}$ & $\begin{array}{c}\text { Idle Space } \\
\text { utility }\end{array}$ \\
\hline Odd Semester & 16 & 40 & 8 & 17,53 & 82,47 \\
\hline even Semester & 16 & 40 & 8 & 10,85 & 89,15 \\
\hline Odd Semester & 16 & 40 & 6 & 31,16 & 68,84 \\
\hline even Semester & 16 & 40 & 6 & 19,29 & 80,71 \\
\hline Odd Semester & 16 & 30 & 8 & 23,37 & 76,63 \\
\hline even Semester & 16 & 30 & 8 & 14,47 & 85,53 \\
\hline Odd Semester & 16 & 30 & 6 & 41,55 & 58,45 \\
\hline even Semester & 16 & 30 & 6 & 25,72 & 74,28 \\
\hline Odd Semester & 16 & 20 & 8 & 35,06 & 64,94 \\
\hline even Semester & 16 & 20 & 8 & 21,7 & 78,3 \\
\hline Odd Semester & 16 & 20 & 6 & 62,33 & 37,67 \\
\hline even Semester & 16 & 20 & 6 & 38,58 & 61,42 \\
\hline
\end{tabular}

Untuk fakultas teknik, bila kapasitas maksimumnya di tetapkan 20 mahasiswa per ruangan untuk satu mata kuliah, maka space -utility nya meningkat menjadi 35,06 untuk semester ganjil dan 21,7 untuk semester genap, dengan catatan pemakaian ruangan dalam satu hari adalah 8 jam. Jika meningkatkan jumlah mahasiswa, maka universitas pakuan harus meningkatkan promosinya untuk fakultas teknik. Dengan meningkatkan jumlah masiswa, maka akan terjadi kelas paralel untuk suatu mata kuliah. Selanjutnya ada konsekuensinya harus melakukan penambahan tenaga pengajar/ dosen, agar rasio dosen mahasiswa tetap memenuhi 1:20. 


\section{KESIMPULAN DAN SARAN}

Kesimpulan dari penelitian ini adalah :

1. Persentase frekunsi pemakaian ruangan rata-rata di fakultas teknik UNPAk adalah 51,04\% untuk semester ganjil dan 38,28\% untuk semester genap

2. Okupansi pemakaian ruangan rata-rata di fakultas teknik UNPAk adalah $34,34 \%$ untuk semester ganjil dan 28,35\% untuk semester genap

3. Space utility untuk semester ganjil adalah 17,53 persen dan space utility untuk semester genap adalah 10,85\%. Space utiliy rata-ratanya adalah $14,19 \%$

4. Idle space utility nya adalah $85,81 \%$

Saran yang dapat diberikan adalah :

1. Universitas Pakuan, dalam hal ini fakultas teknik harus meningkatkan promosinya untuk meningkatkan jumlah mahasiswa yang kuliah agar tingkat okupansinya meningkat dan frekuensi penggunaan ruangan juga meningkat.

2. Jika jumlah mahasiswa meningkat, maka sebagai dampaknya juga harus menambah tenaga pengajar/ dosen.

\section{DAFTAR PUSTAKA}

Fakultas Teknik Universitas Pakuan (2011). Portofolio Fakultas Teknik.

Hesti Maheswari.(2010).Optimasi Kapasitas Dalam Meningkatkan Efisiensi dan Pengembalian Investasi (Studi Kasus pada Universitas Mercu Buanan Jakarta). Pamator, Volume 3, nomor 2, Oktober 2010.

Heizer J \& Render Barry. (2008) Operation Management, 6th edition, Prentice-Hall International Inc., New Jersey.

Martinich, Joseph S. (1997) Production and Operation Management An Applied Modem Approach, John Willey \& Suns Inc., New York.

Standar Nasional Pendidikan.(2005). Peraturan Pemerintah Nomor 19 tahun 2005 tentang Standar Nasional Pendidikan.

UK Higher Education. (2006). Space Management Project, Space utilisation: practice, performance and guidelines. 